\title{
UPOTREBA ANTIBIOTIKA U ODNOSU NA PREPORUKE ZA LIJEČENJE AKUTNIH RESPIRATORNIH INFEKCIJA U PORODIČNOJ MEDICINI
}

\author{
ANTIBIOTIC USE RELATED TO RECOMMENDATIONS FOR TRETMENT OF ACUTE \\ RESPIRATORY INFECTIONS IN FAMILY MEDICINE
}

Marković Brankica, Stanetić Kosana, Petrović Verica, Mijatović Zoran

\begin{abstract}
Sažetak
Uvod: Akutne respiratorne infekcije (ARI) su jedan od najčešćih razloga za posjetu porodičnom ljekaru. Iako su virusi odgovorni za većinu ARI, upotreba antibiotika u ovim oboljenjima često je visoka. U Republici Srpskoj, porodičnim ljekarima su na raspolaganju vodiči za najčešće akutne respiratorne infekcije djece i odraslih.

Cilj:Procjena učestalosti propisivanja antibiotika kod ARI u porodičnoj medicini Doma zdravlja Banja Luka i usklađenost propisane antibiotske terapije sa vodičima za ARI.

Metode: Provedena je retrospektivna studija u devet timova porodične medicine Doma zdravlja Banja Luka od 1. januara do 31. decembra 2017.godine. Analizirani su oboljeli od akutnih sinusitisa, tonzilofaringitisa, bronhitisa, pneumonija i nespecifičnih upala donjih respiratornih puteva. Analizirane su sociodemografske karakteristike ispitanika, eventualni antibiotski tretman i da li je antibiotski tretman u skladu sa vodičima za ARI.

Rezultati:Od ukupno 2446 ispitanika,čak2035 (83,2\%) dobilo je antibiotik. Antibiotici su bili nezaobilazni u liječenju tonzilitsa i pneumonija gde je zastupljenost bila preko 95\%. Čak 60,7\% propisanih antibiotika nije bilo prema preporukama ARI vodiča.Penicilinski antibiotici su propisani u 67\% slučajeva. Najpropisivaniji antibiotik bio je amoksicilin 822 (40,4\%), zatim slijede fenoksimetilpenicilin 318 (15,6\%), azitromicin 239 (11,7\%), doksiciklin 225 (11,1\%), te amoksicilin sa klavulanskom kiselinom 196 (9,5\%).

Zaključak:U radu porodičnih ljekara, antibiotici su bili visoko zastupljeni u liječenju ARI.Primjena vodiča prilikom odabira antibiotikaza liječenjeARI je bila neprimjereno mala.Ljekari češće propisuju antibiotik prvog izbora u liječenju akutnih tonzilitisa i sinusitisa, nego u liječenju akutnih faringitisa, bronhitisa i pneumonija.

Ključne riječi:ARI, antibiotici, vodiči za ARI
\end{abstract}

\section{Uvod}

Prema podacima Instituta za javno zdravstvo Republike Srpske za 2016. godinu, bolesti organa za disanje obuhvatale su ukupno $13,84 \%$ svih ambulantnih prvih pregleda porodičnih ljekara i $15,46 \%$ prvih pregleda porodičnih ljekara na područiju grada Banja Luka [1]. ARI su najčešći uzročnici morbiditeta u SAD. Podaci iz literature u Velikoj Britaniji ukazuju da četvrtina populacije posjeti svog porodičnog ljekara svake godine zbog respiratornih infekcija [2].

Antibiotici možda jesu bili prekretnica moderne medicine, te su izliječili i spasili veliki broj ljudskih života, ali njihovo neracionalno i neopravdano trošenje dovelo je do krize antibiotske rezistencije.
Povećanje učestalosti, širenja i jačanja rezistentnih bakterija koje se pojavljuju u cijelom svijetu dovelo je do preispitivanja njihove upotrebe i efikasnosti. Rezistencija raste, a farmaceutska industrija kaska u pronalaženju odgovarajuće zamjene i jačanja već postojeće antimikrobne palete lijekova. Najvažnije posljedice antimikrobne rezistencije su povećanje stope mortaliteta, produženo liječenje i povećanje troškova liječenja kod infekcija izazvanih razistentnim mikrobima [3,4]. Tako, izvještaji Svjetske zdravstve organizacije (SZO) za 2014. navode Streptococcus pneumoniae kao jedan od najčešćih uzročnika infekcija u vanbolničkim uslovima ali i visoku stopu penicilinske rezistencije na ovu bakteriju i do $50 \%$ u nekim geografskim oblastima [5]. 
Antibiotska rezistencija postaje jedan od najtežih zadataka moderne medicine. U Republici Srpskoj ljekari porodične medicine imaju na raspolaganju nekoliko kliničkih vodiča, u cilju poboljšanja kvaliteta rada, zadovoljstva pacijenata, racionalizacije i smanjenja troškova zdravstvenog osiguranja. Ovi vodiči se osvrću na najčešća oboljenja u porodičnoj medicini, a posvećena je velika pažnja akutnim respiratornim infekcijama kod djece i odraslih, kao bolestima sa kojima se ljekari u primarnoj praksi često sreću. Prema važećem vodiču za akutne respiratorne infekcije djece i odraslih, antibiotike treba koristiti samo u određenim okolnostima i tada treba da se daju ciljano za najučestalije bakterijske patogene, ali i da budu što užeg spektra djelovanja. Kao najčešći lijek prvog izbora preporučuju se penicilini, uskog spektra djelovanja (fenoksimetilpenicilin, prokain i benzatil benzilpenicilin), rjeđe drugi $\beta$-laktami, a u slučaju preosjetljivosti na lijekove iz penicilinske grupe preporučuju se lijekovi izgrupe makrolida (eritromicin, klaritromicin, azitromicin) [6].

Istraživanje o upotrebi antibiotika u Republici Srpskoj objavljeno 2018. godine navodi da je upotreba antibiotika u šestogodišnjem periodu praćenja bila relativno konstantna i da se u zadnjim godinama bilježi pad upotrebe antibiotika. Penicilin i amoksicilin su bili najpropisivaniji antibiotici, a uočen je porast upotrebe amoksicilina sa klavulinkom kiselinom, azitromicina i fluorohinolona [7].

Kao što je preporučeno u drugim sličnim vodičima za ARI u svijetu, smatra se da je najbolji pristup liječenju respiratornih infekcija, izuzev pneumonija, čekanje i opservacija pacijenta. Antibiotike bi trebalo izbjegavati u najvećem broju slučajeva, a lijekovi bi trebalo da se daju simptomatski.U slučaju pogoršanja i prolongiranja bolesti, dijagnozu bi trebalo revidirati i razmotriti eventualnu antibiotsku terapija [8 - 12].

U Sjedinjenim Američkim Državama (SAD), približno $75 \%$ svih antibiotika propisanih ambulantno odnosi se na pet najčešćih vanbolničkih infekcija: otitis media, sinusitis, faringitis, bronhitis i infekcije gornjih respiratornih puteva. Iako su najučestaliji patogeni virusi, čak u $85 \%$ slučajeva, simptomatsku terapiju prati popisivanje antibiotika. Prema američkim studijama čak $90 \%$ antibiotika za vanbolničke infekcije bivaju propisani od strane ljekara na primarnom nivou zdravstvene zaštite (pedijatri, porodični ljekari, ljekari opšte prakse i internisti). A upravo respiratorne infekcije su na liderskoj poziciji dijagnoza koje prati propisivanje antibiotika, sa preko 50\% udjela. U Velikoj Britaniji $60 \%$ svih antibiotika $u$ porodičnoj medicini je propisano za respiratorne infekcije. Procjenjuje se da se za liječenje akutnog kašlja godišnje izdvoji preko 15 miliona funti [2].

\section{Ciljevi}

1. Procijeniti učestalost propisivanja antibiotske terapije kod akutnih respiratornih infekcija $u$ porodičnoj medicini Doma zdravlja Banja Luka

2. Procijeniti usklađenost propisivane antibiotske terapije i smjernica važećih vodiča za akutne respiratorne infekcije u porodičnj medicini

\section{Uzorak i metode rada}

Istraživanje je provedeno retrospektivnim uzimanjem podataka iz elektronskihzdravstvenih kartona iz programa Web-medic u periodu od 01.01.2017. do 31.12.2017.

Izvlačenjem brojeva timova porodične medicine iz šešira, odabrana su po tri tima iz gradskih,

prigradskih i ruralnih ambulanti Doma zdravlja Banja Luka.

Kriterijumi za uključivanje ispitanika u istraživanje su bili:

- da ispitanik ima jednu od sledećih dijagnoza respiratornih infekcija poMeđunarodnoj klasifikaciji bolesti, 10. revizija (MKB-10): rhinosinusitis acuta(J01), pharyngitis acuta (J02), tonsilitis acuta (J03), pneumonia (J18), bronchitisacuta (J20) i infectio respiratoria inferior acuta, non specificata (J22);

- da je dijagnozu postavio i terapiju ordinirao porodični ljekar;

- da ispitanik ima 6 i više godina.

Kriterijumi za neuključivanje pacijenata $u$ istraživanje su bili:

- da je dijagnozu postavio i terapiju ordinirao ljekar druge grane medicine;

- ako ima dijagnozu akutne infekcije gornjih respiratornih puteva (po MKB-10) infectiones tractus respiratorii superior acutae, loci non specificati - J06) koja je najčešće virusna i za koju ne postoji klinički vodič u Republici Srpskoj. 
Podaci koji su uzimani iz zdravstvenog kartona bili su slijedeći: datum pregleda, pol,dob, dijagnoza akutne respiratorne infekcije, da li je propisan antibiotik, generički naziv ordiniranog antibiotika, kao i da li je ordinirani antibiotik bio, prema prepreporukama važećih vodiča za ARI, lijek prvog ili drugog izbora (Tabela 1). Budući da nemamo nacionali vodič za akutne sinusitise, korištene su američke preporuke $[13,14]$. Datum pregleda se koristio usvrhu ocjenjivanja učestalosti javljanja analiziranog oboljenja u nekom periodu godine.

U cilju statističke obrade, ispitanici su u odnosu a dob podjeljeni u 4 grupe: od 6-18 godina, 19-45 godina, 46-64 godine $i \geq 65$ godina.

Tabela 1. Antibiotici prvog i drugog izbora za analizirana oboljenja [6, 13,14]

\begin{tabular}{|c|c|c|}
\hline Dijagnoza & $\begin{array}{l}\text { Antibiotici prvog } \\
\text { izbora }\end{array}$ & $\begin{array}{l}\text { Antibiotici } \\
\text { drugog izbora }\end{array}$ \\
\hline $\begin{array}{l}\text { Sinusitis acuta } \\
\text { (J01) }\end{array}$ & $\begin{array}{lll}\text { Amoksicilin } & \\
\text { Amoksicilin } & + \\
\text { klavulanska kiselina } \\
\text { Cefalosporini II } & \text { i } & \text { III } \\
\text { generacije }(\leq & 18 \\
\text { godina alergični na } \\
\text { amoksicilin) }\end{array}$ & 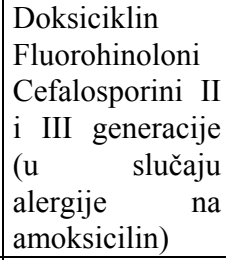 \\
\hline $\begin{array}{l}\text { Tonsillopharingitis } \\
\text { acuta }(J 02+J 03)\end{array}$ & $\begin{array}{l}\text { Penicilin } \\
\text { (fenoksimetilpenicilin } \\
\text { prokain } \\
\text { benzilpenicilin, } \\
\text { benzatin } \\
\text { benzilpenicilin) }\end{array}$ & $\begin{array}{l}\text { Eritromicin } \\
\text { Klaritromicin } \\
\text { Azitromicin } \\
\text { (kod odraslih) }\end{array}$ \\
\hline $\begin{array}{l}\text { Bronchititis acuta } \\
\text { (J20) }\end{array}$ & $\begin{array}{l}\text { (Antibiotici nisu } \\
\text { indikovani- uglavnom } \\
\text { virusna etiologija, a } \\
\text { ako se propisuju to } \\
\text { su:) } \\
\text { Amoksicilin } \\
\text { Kotrimoksazol } \\
\text { Eritromicin }\end{array}$ & $\begin{array}{l}\text { Klaritromicin } \\
\text { Azitromicin } \\
\end{array}$ \\
\hline \multirow[t]{2}{*}{$\begin{array}{l}\text { Pneumonia }(J 18) \\
\text { Infectio } \\
\text { respiratoria } \\
\text { inferior acuta, non } \\
\text { specificata }(J 22)\end{array}$} & $\begin{array}{l}\text { Mlađi od } 15 \text { godina: } \\
\text { Eritromicin } \\
\text { Fenoksimetilpeniclin }\end{array}$ & $\begin{array}{ll}\text { Mlađi od } 15 \\
\text { godina: } \\
\text { Amoksicilin } \\
\text { Amoksicilin } \quad+ \\
\text { klavulanska } \\
\text { kiselina } \\
\text { Azitromicin } \\
\end{array}$ \\
\hline & $\begin{array}{ll}\text { Stariji od } 16 \text { godina: } \\
\text { Amoksicilin } \\
\text { Amoksicilin } \\
\begin{array}{ll}\text { klavulanska kiselina } \\
\text { Cefalosporini } \\
\text { generacije }\end{array} \quad 2 \\
\end{array}$ & $\begin{array}{l}\text { Stariji od } 16 \\
\text { godina: } \\
\text { Eritromicin } \\
\text { Klaritromicin } \\
\text { Azitromicin } \\
\text { Ciprofloksacin } \\
\text { (Fluorohinoloni } \\
\text { ) }\end{array}$ \\
\hline
\end{tabular}

Od statističkih metoda u poređenju kategorijskih varijabli korišteni su $\chi 2$ test i Student-ov T - test. U primijenjenim analitičkim metodama nivo značajnosti bio je $\mathrm{p}<0.05$.

\section{Rezultati}

Ispitivanjem je obuhvaćeno 2446 oboljelih od akutnih respiratornih infekcija. Statistički značajno više $(\mathrm{p}=0,015)$ su bile zastupljene osobe ženskog pola 1337 (54,7\%), nego muškog pola 1109 $(45,3 \%)$. Statistički značajno najviše oboljelih $(\mathrm{p}=0,015)$ je nađeno je u prigradskim ambulantama 969 (39,6\%), a najmanje u ruralnim ambulantama.Prevalencija obolijevanja od ARI opada sa godinama života uz statistički visoko značajnu razliku $(\mathrm{p}=0,000)$. Prosječna starost ispitanika muškog pola bilaje oko 32 godine, a ispitanika ženskog pola oko 38 godina života $(\mathrm{p}=0,018)$ (Tabela 2).

Tabela 2. Sociodemografske karakteristike ispitanika

\begin{tabular}{|c|c|c|}
\hline Varijable & $\begin{array}{l}\text { Ispitanici } \\
\mathbf{N}(\%)\end{array}$ & $\mathbf{p}^{*}$ \\
\hline \multicolumn{2}{|l|}{ Pol } & \multirow{4}{*}{0,015} \\
\hline muški & $1109(45,3)$ & \\
\hline ženski & $1337(54,7)$ & \\
\hline ukupno & $2446(100)$ & \\
\hline \multicolumn{2}{|c|}{ Mjesto stanovanja } & \multirow{4}{*}{0,015} \\
\hline gradsko & $785(32,1)$ & \\
\hline prigradsko & $969(39,6)$ & \\
\hline ruralno & $692(28,3)$ & \\
\hline \multicolumn{2}{|l|}{ Dob } & \multirow{5}{*}{0,000} \\
\hline 6-18 godina & $848(34,7)$ & \\
\hline 19-45 godina & $753(30,8)$ & \\
\hline 45-64 godina & $509(20,8)$ & \\
\hline$\geq 65$ godina & $335(13,7)$ & \\
\hline \multicolumn{2}{|c|}{ Prosjek godina života } & \multirow{3}{*}{0,018} \\
\hline muškarci & 32,32 & \\
\hline žene & 37,88 & \\
\hline
\end{tabular}

Akutni faringitis je dijagnostikovan u 1115 $(45,58 \%)$ bolesnika, što ga čini najučestalijom ARI uz visoku statističku značajnost $(\mathrm{p}=0,000)$. Upale pluća (J18) i nespecifične infekcije donjih disajnih puteva (J22) češće su dijagnostikovane u starijim dobnim grupama, dok su ostale ARI češće dijagnostikovane $\mathrm{u}$ mlađim dobnim grupama uz visoku statističku značajnost $(\mathrm{p}=0,000)$. Oboljeli su se statistički značajno $(\mathrm{p}=0,003)$ češće javljali na 
pregled u prva tri mjeseca 2017.godine, a najmanje u ljetnim mjesecima (Tabela 3,Grafikon 1).

Tabela 3. Zastupljenost akutnih respiratornih infekcija u odnosu na dob

\begin{tabular}{|c|c|c|c|c|c|c|}
\hline Broj oboljelih & J01 & $\mathrm{J02}$ & J03 & $\mathbf{J 1 8}+\mathbf{J} 22$ & $\mathbf{J 2 0}$ & $p^{*}$ \\
\hline Ukupno N(\%) & $\begin{array}{l}319 \\
(13,04)\end{array}$ & $1115(45,58)$ & $547(22,36)$ & $\begin{array}{l}153 \\
(6.26)\end{array}$ & $312(12,76)$ & 0,000 \\
\hline \multicolumn{7}{|c|}{ Prema dobnim grupama } \\
\hline 6-18godina & $64(20,1)$ & $405(36,3)$ & $264(48,3)$ & $\begin{array}{l}13 \\
(8,5)\end{array}$ & $103(33,0)$ & \multirow{4}{*}{0,000} \\
\hline 19-44 godina & $\begin{array}{l}154 \\
(48,3)\end{array}$ & $317(28,4)$ & $195(35,6)$ & $\begin{array}{l}26 \\
(17,0)\end{array}$ & $61(19,6)$ & \\
\hline 45-64 godina & $75(23,4)$ & $237(21,3)$ & $65(11,9)$ & $\begin{array}{l}56 \\
(36,6)\end{array}$ & $76(24,3)$ & \\
\hline$\geq 65$ godina & $\begin{array}{l}26 \\
(8,2)\end{array}$ & $156(14,0)$ & $\begin{array}{l}23 \\
(4,2)\end{array}$ & $\begin{array}{l}58 \\
(37,9)\end{array}$ & $72(23,1)$ & \\
\hline
\end{tabular}

${ }^{*}$ statistička značajnost na nivou p $\quad 0,005^{* *}$ ARI - akutna respiratorna infekcija

Grafikon 1. Broj oboljelih prema mjesecu javljanja na pregled

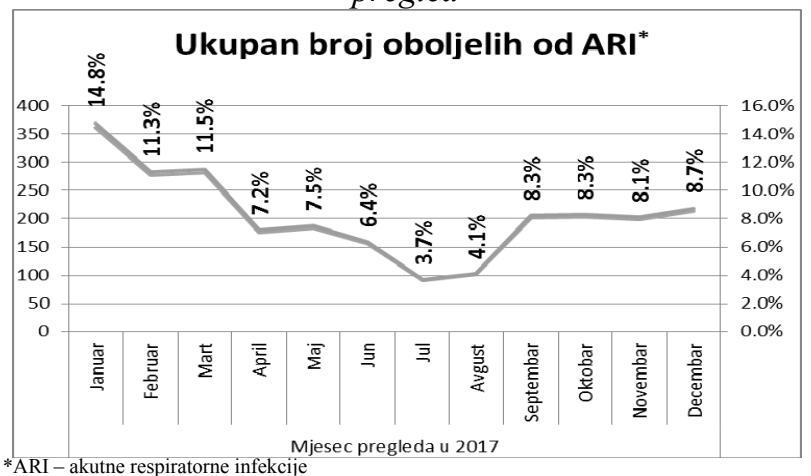

U jednogodišnjem periodu praćenja, čak 2035 $(83,2 \%)$ oboljelih je liječeno antibiotikom $(\mathrm{p}=0,000)$. Najčešće su oboljeli od ARI liječeni antibiotikom u prigradskim ambulantama, u 845 $(87,2 \%)$ slučaja. Oboljeli od ARI su u svim dobnim grupama u visokom procentu liječeni antibiotikom, u dobi od 6 - 18 godina u $639(75,3 \%)$ slučajeva, a u populaciji preko 65 godina u $309(92,2 \%)$ slučajeva uz visoku statističku značajnost $(p=0,000)$. Izostanak antibiotske terapije je statistički značajnije $(\mathrm{p}=0,265)$ zabilježen $\mathrm{u}$ oboljelih od akutnih faringitisa $268(24,0 \%)$ i akutnih bronhitisa 71 $(22,8 \%)$, dok su oboljeli od pnumonija i tonzilitisa imali jako visoku zastupljenost antibiotika u terapiji sa preko 95\% (Tabela 4).
Tabela 4. Upotreba antibiotika kod oboljelih od akutnih respiratornih infekcija u odnosu na mjesto stanovanja, životnu dob i dijagnozu

\begin{tabular}{|c|c|c|c|}
\hline \multirow[t]{2}{*}{ Varijable } & \multicolumn{2}{|c|}{ Antibiotici N(\%) } & \multirow[t]{2}{*}{$p^{*}$} \\
\hline & da & ne & \\
\hline \multicolumn{4}{|c|}{ Prema mjestu stanovanja } \\
\hline gradsko & $669(85,2)$ & $116(14,8)$ & \multirow{4}{*}{0,000} \\
\hline prigradsko & $845(87,2)$ & $124(12,8)$ & \\
\hline ruralno & $521(75,3)$ & $171(24,7)$ & \\
\hline ukupno & $2035(83,2)$ & $411(16,8)$ & \\
\hline \multicolumn{4}{|c|}{ Prema starosnim grupama } \\
\hline 6-18godina & $639(75,3)$ & $210(24,7)$ & \multirow{4}{*}{0,000} \\
\hline $19-44$ godina & $654(86,8)$ & $99(13,2)$ & \\
\hline 45-64 godina & $433(85,1)$ & $76(14,9)$ & \\
\hline$\geq 65$ godina & $309(92,2)$ & $26(7,8)$ & \\
\hline \multicolumn{4}{|c|}{ Prema dijagnozama } \\
\hline J01 - - & $279(87,5)$ & $40(12,5)$ & \multirow{5}{*}{0,265} \\
\hline $\mathbf{J 0 2}$ & $847(76,0)$ & $268(24,0)$ & \\
\hline J03 & $521(95,2)$ & $26(4,8)$ & \\
\hline J18+J22 & $147(96,1)$ & $6(3,9)$ & \\
\hline J20 & $241(77,2)$ & $71(22,8)$ & \\
\hline
\end{tabular}

* statistička značajnost na nivou p $\quad 0,005$

Ljekari porodične medicine najviše su se pridržavali vodiča u liječenju akutnih tonzilitisa i akutnih sinusitisa, gdje je antibiotik prvog izbora propisan kod $309(55,2 \%)$, odnosno kod 125 $(44,8 \%)$ oboljelih. Ljekari porodične medicine su se statistički značajno manje $(\mathrm{p}=0,000)$ pridržavali vodiča u liječenju akutnog faringitisa, gde je u 736 $(86,9 \%)$ ispitanika propisan antibiotik koji nije u skladu sa važećim vodičem (Tabela 5).

Tabela 5.Upotreba antibiotika u odnosu na preporuke za liječenje akutnih respiratornih infekcija

\begin{tabular}{|l|l|l|l|l|l|l|}
\hline & \multicolumn{1}{|l|}{ Antibiotik izbora } & & $\chi^{2}$ & $\mathbf{p}^{*}$ \\
\hline Dijagnoze & $\begin{array}{l}\text { Prvog } \\
\text { izboraN(\%) }\end{array}$ & $\begin{array}{l}\text { Drugog } \\
\text { izboraN(\%) }\end{array}$ & $\begin{array}{l}\text { Nije } \\
\text { preporukamaN(\%) }\end{array}$ & prema & $\begin{array}{l}\text { Ukupno } \\
\text { N(\%) }\end{array}$ & \\
\hline
\end{tabular}




\begin{tabular}{|l|l|l|l|l|l|l|}
\hline J01 & $125(44,8)$ & $50(17,9)$ & $104(37,3)$ & $279(13,7)$ & & \multirow{2}{*}{0,000} \\
\hline J02 & $53(6,3)$ & $58(6,8)$ & $736(86,9)$ & $847(41,7)$ & $521(25,6)$ & 710,7 \\
\hline J03 & $309(55,2)$ & $21(4,1)$ & $191(36,7)$ & $147(7,2)$ & \\
J18+J22 & $20(3,6)$ & $55(37,4)$ & $72(49,0)$ & $241(11,8)$ & \\
\hline J20 & $53(22,0)$ & $56(23,2)$ & $132(54,8)$ & $2035(100)$ & \\
\hline Ukupno & $560(27,5)$ & $240(11,8)$ & $1235(60,7)$ & & \\
\hline
\end{tabular}

* statistička značajnost na nivou p $\quad 0,005$

Najzastupljeniji antibiotik bio je amoksicilin, a propisan je kod 822 (40,4\%) oboljelih. Fenoksimetil penicilin se kao terapija izbora koristio u 318 $(15,6 \%)$ pregleda. Azitromicin je propisan u 239 $(11,7 \%)$, a doksiciklin kod 225 (11,1\%) oboljelih. Amoksicilinom su uglavnom liječeni akutni fatingitisi u čak 595 (70,2\%) slučajeva. Antibiotska terapija fenoksimetil penicilinom bila je najčešće primjenjivana $\mathrm{u}$ akutnim tonzilitisima, te su ljekari ispratili vodič u $274 \quad(52,7 \%)$ slučajeva. Zastupljenost azitromicina bila je veća kod pneumonija sa $24(36,4 \%)$ i akutnih bronhitisa sa 83 $(34,4 \%)$ slučaja. Slična situacija se mogla primjetiti kod propisivanja doksiciklina. Podaci o propisivanju antibotika, prema generičkim nazivima, prikazani su u tabeli 6 .

Tabela 6. Antibiotska terapija prema dijagnozi akutne respiratorne infekcije

\begin{tabular}{|c|c|c|c|c|c|c|c|c|c|}
\hline \multicolumn{8}{|l|}{ Dijagnoza } & $x^{2}$ & p* \\
\hline Antibiotik & $\begin{array}{l}\text { J01 } \\
\text { N(\%) }\end{array}$ & $\begin{array}{l}\mathrm{J} 02 \\
\mathrm{~N}(\%)\end{array}$ & $\begin{array}{l}\text { J03 } \\
\text { N (\%) }\end{array}$ & $\begin{array}{l}\text { J18 } \\
N(\%)\end{array}$ & $\begin{array}{l}J 20 \\
N(\%)\end{array}$ & $\begin{array}{l}\mathrm{J} 22 \\
\mathrm{~N}(\%)\end{array}$ & $\begin{array}{l}\text { Ukupno } \\
\mathrm{N}(\%)\end{array}$ & \multirow{20}{*}{2027,7} & \multirow{20}{*}{0,000} \\
\hline FMP ${ }^{* *}$ & $2(0,7)$ & $42(5,0)$ & $274(52,6)$ & $0(0,0)$ & $0(0,0)$ & $0(0,0)$ & $318(15,6)$ & & \\
\hline $\mathbf{P B P}^{* * *}$ & $0(0,0)$ & $2(0,2)$ & $25(4,8)$ & $0(0,0)$ & $0(0,0)$ & $0(0,0)$ & $27(1,3)$ & & \\
\hline Amoskicilin & $42(15,1)$ & $595(70,2)$ & $131(25,1)$ & $1(1,5)$ & $50(20,7)$ & $3(3,7)$ & $822(40,4)$ & & \\
\hline$A K^{* * * * *}$ & $79(28,3)$ & $51(6,0)$ & $35(6,7)$ & $4(6,1)$ & $16(6,8)$ & $11(13,7)$ & $196(9,5)$ & & \\
\hline Cefaleksin & $36(12,9)$ & $26(3,1)$ & $5(1,0)$ & $2(3,0)$ & $12(5,0)$ & $0(0,0)$ & $81(4,0)$ & & \\
\hline Cefuroksim & $4(1,4)$ & $1(0,1)$ & $0(0,0)$ & $0(0,0)$ & $1(0,4)$ & $3(3,7)$ & $9(0,4)$ & & \\
\hline Cefaklor & $1(0,4)$ & $0(0,0)$ & $0(0,0)$ & $0(0,0)$ & $0(0,0)$ & $0(0,0)$ & $1(0,1)$ & & \\
\hline Cefiksim & $0(0,0)$ & $0(0,0)$ & $0(0,0)$ & $1(1,5)$ & $0(0,0)$ & $1(1,2)$ & $2(0,1)$ & & \\
\hline Eritromicin & $0(0,0)$ & $9(1,1)$ & $14(2,6)$ & $0(0,0)$ & $0(0,0)$ & $1(1,2)$ & $24(1,2)$ & & \\
\hline Azitromicin & $46(16,5)$ & $72(8,5)$ & $30(5,8)$ & $24(36,4)$ & $55(22,8)$ & $12(14,8)$ & $239(11,7)$ & & \\
\hline Klaritromicin & $13(4,7)$ & $1(0,1)$ & $2(0,4)$ & $5(7,6)$ & $3(1,3)$ & $6(7,4)$ & $30(1,5)$ & & \\
\hline Ciprofloksacin & $7(2,5)$ & $1(0,1)$ & $0(0,0)$ & $9(13,6)$ & $15(6,2)$ & $0(0,0)$ & $32(1,6)$ & & \\
\hline Levofloksacin & $0(0,0)$ & $1(0,1)$ & $0(0,0)$ & $3(4,5)$ & $2(0,8)$ & $3(3,7)$ & $9(0,4)$ & & \\
\hline Moksifloksacin & $0(0,0)$ & $0(0,0)$ & $1(0,2)$ & $0(0,0)$ & $0(0,0)$ & $0(0,0)$ & $1(0,1)$ & & \\
\hline Kotrimoksazol & $6(2,1)$ & $3(0,4)$ & $1(0,2)$ & $1(1,5)$ & $3(1,2)$ & $0(0,0)$ & $14(0,7)$ & & \\
\hline Doksiciklin & $43(15,4)$ & $42(5,0)$ & $3(0,6)$ & $13(19,8)$ & $83(34,4)$ & $41(50,6)$ & $225(11,1)$ & & \\
\hline Midekamicin & $0(0,0)$ & $1(0,1)$ & $0(0,0)$ & $0(0,0)$ & $0(0,0)$ & $0(0,0)$ & $1(0,1)$ & & \\
\hline Garamicin & $0(0,0 \%)$ & $0(0,0)$ & $0(0,0)$ & $3(4,5)$ & $1(0,4)$ & $0(0,0)$ & $4(0,2)$ & & \\
\hline Ukupno & $279(13,7)$ & $\begin{array}{l}847 \\
(41,7)\end{array}$ & $\begin{array}{l}521 \\
(25,6)\end{array}$ & $\begin{array}{l}66 \\
(3,2)\end{array}$ & $\begin{array}{l}241 \\
(11,8)\end{array}$ & $\begin{array}{l}81 \\
(4,0)\end{array}$ & $2035(100)$ & & \\
\hline
\end{tabular}

* statistička značajnost na nivou p $\quad 0,005$

${ }^{* *}$ Fenoksimetil penicilin

${ }^{* * *}$ Prokain benzilpenicilin

*****Amoksicilin sa klavulanskom kiselinom

\section{Diskusija}

Jednogodišnjim istraživanjem $\mathrm{u}$ devet timova porodične medicine grada Banja Luka dijagnostiovano je ukupno 2446 oboljelih od ARI koji su ispunili kriterijume ispitivanja. Najmasovniju grupu oboljelih od 1262 (51,6\%) činili su ispitanici starosti od 19-64 godine, sa većom zastupljenošću ženskog pola $(54,7 \%)$. Oboljeli muškog pola su češće bili zastupljeni u starosnoj grupi od 6-18 godina, a slični podaci 
nalaze se $u$ evropskim $i$ američkim istraživanjima. Prosječna starost ispitanika iznosila je 34 godine i bila je nešto niža nego u sličnim istraživanjima[15 -17].

Dijagnoza akutnog faringitisa potvrđena je u $1115(45,58 \%)$ ispitanika, čineći ga tako najčešćim oboljenjem. S druge strane, učestalost pneumonije i nespecifičnih oboljenja donjih respirtatornih puteva bila je znatno manja, sa udjelom od 6,26\% oboljelih. U evropsko-američkoj literaturi uočava se znatno veća zastupjenost infekacija donjih disajnih puteva, najviše $u$ ispitivanjima rađenim $u$ Sjedinjenim Američkim Državama, Ujedinjenom Kraljevstvu i skandinavskim zemljama. Razlog ovome, može da leži u metodologiji ispitivanja, gdje zadata oboljenja koja su liječena od strane specijalista sa sekundarnog nivoa zdravstvene zaštite, nisu bila obuhvaćena našim istraživanjem. Holandska studija iz 2016.godine takođe spominje ovu problematiku [18].

Našom studijom je utvrđeno 2035 (83,2\%) oboljelih od ARI koji su liječeni antibiotikom. Pod pretpostavkom da antibiotici nisu indikovani za liječenje većine gornjih ARI i akutnih bronhitisa, vrlo je vjerovatna neopravdanost većine propisanih antibiotika. Ispitivanje provedeno među ljekarima i pacijentima u Irskoj navodi multiple faktore koji utiču na odluku o propisivanju antibiotika, među kojima su skraćeno vrijeme pregleda, pacijentov stav prema antibiotiku, duži radni staž ljekara, participacija, očekivanja i niža stručna sprema pacijenta[19].

Hrvatska studija, sprovedena na područiju grada Splita tokom 2015. godine, pokazala je slične rezultate kao i naša studija vezano za primjenu antibiotske terapije u respiratornim oboljenima [25]. Podaci iz evro-atlantskih studija su različiti, te su se u zavisnosti od oboljenja udjeli antibiotika u terapiji ARI kretali od oko $35 \%$ do $80 \%$ [17, 20 - 22].

U našoj studiji, čak $67 \%$ svih propisanih antibiotika bili su iz penicilinske grupe. Zatim slijede makrolidi sa $14,4 \%$ i tetraciklini sa $11,1 \%$. Studija o korišćenju antibiotika u Republici Srpskoj, iz 2018.godine, utvrdila je dominantnu zastupljenost penicilinskih preparata u liječenju infekcija [7]. Penicilinski antibiotici su i dalje najpropisivaniji antimikrobni agensi u svjetu, a dominaciju potkrepljuju i podaci iz 2016.godine objedinjeni u epidemiološkom izvještaju Evropskog centra za prevenciju i kontrolu bolesti [16, 17, 21, 23, 24].
Antibiotskom terapijom najčešće su liječeni naši ispitanici starije životne dobi ( $\geq 65$ godina) u $92,2 \%$ slučajeva, a najmlađi ispitanici u $75,3 \%$ slučajeva. U najstarijoj dobnoj grupi registruje se smanjenje upotrebe penicilinskih i makrolidnih antibiotika, a vidljiva je veća zastupljenost fluorohinolonskih i tetraciklinskih antibiotika. Slični rezultati zapaženi su u britanskoj studiji, objavljenoj 2018.godine [16].

Penicilini su daleko češće bili propisivani $u$ infekcijama gornjih respiratornih puteva (J01, J02 i J03), dok je udio makrolida i tetraciklina bio znatno veći u donjim respiratornim infekcijama (J18, J20 i J22). Amoksicilinom je liječeno 822 (40,4\%) oboljelih i to je bio najčešće propisivan antibiotik. $\mathrm{Da}$ je amoksicilin najčešće propisivan antibiotik $u$ ARI, potvrđeno je i u studiji o upotrebi antibiotika u šestogodišnjem periodu za sve indikacije $u$ Republici Srpskoj iz 2018.godine [7].U našoj studiji, penicilin uskog spektra propisan je kod 345 $(16,9 \%)$ oboljelih, zatim slijede azitromicin sa 239 $(11,7 \%)$, doksiciklin sa $225(11,1 \%)$, i kombinacija amoksicilina i klavulanske kiseline sa 196 (9,5\%) preskripcija. Takođe se uočava daleko manja upotreba antibiotika širokog spektra (npr. amoksicilin sa klavulanskom kiselinom, azitromicin, fluorohinoloni i cefalosporini novijih generacija) $u$ liječenju ARI u odnosu na slične studije u svijetu $[13,22]$. Ovo je vidljivo i u poređenju sa domaćom studijom iz 2018. godine, gdje upotreba šrokospektnih antibiotika ima konstantan rast, a udio ovih lijekova je znatno veći za liječenje ARI nego za druge indikacije [7]. Iz konceptualno slične studije, na područiju grada Splita u Hrvatskoj, utvrđena je visoka upotreba azitromicina i amoksicilina sa klavulanskom kiselinom, od oko $60 \%$ svih propisanih antibiotika [15]. Dominacija antibiotika širokog spektra bila je vidljiva i kod turskih porodičnih ljekara, koji su primat davali kombinaciji amoksicilina ili ampicilina sa $\beta$ laktamskim inhibitorima (klavulanska kiselina, sulbaktam, tazobaktam), u odnosu na samostalnu primjenu istih [24]. Sjevernoevropska literatura pokazuje visoku zastupljenost fenoksimetil penicilina, posebno $u$ liječenju akutnih tonzilofaringitisa, ali i njegovu čestu primjenu $u$ tretmanu donjih respiratornih infekcija. Smatra se da se varijacije $u$ izboru antibiotika mogu pripisati razlikama među nacionalnim vodičima, tradiciji liječenja, marketingu i politikama farmaceutskih kompanija $[16,17,21]$. 
Smatra se da su virusi u 40 do $60 \%$ slučajeva uzročnici svih akutnih faringitisa, a bakterije u 5 do $40 \%$ slučajeva [25]. Veliki broj antimikrobnih lijekova djelotvoran je protiv grupe A streptokoka, npr. penicilini, amoksicilin, cefalosporini i makrolidi. Literatura i dalje prednost daje penicilinu (fenoksimetilpenicilin, benzilpenicilin) zbog dokazane efikasnosti, uskog spektra djelovanja i pristupačne cijene [26].

U našem istraživanju, antibiotska terapija propisana je u $87,5 \%$ svih akutnih sinusitisa. Zastupljenost antibiotika u liječenju sinusitisa u dostupnim literaturama su slične ili donekle niže, a kreću se od oko 65 do $85 \%$ [17, 20,22]. Najpropisivaniji antibiotici za akutne sinusitise u našoj studiji bili su amoksicilin i kombinacija amoksicilina sa klavulanskom kiselinom (43,4\%), a ujedno su oni bili antibiotici prvog izbora [11]. Zastupljenost doksiciklina, kao lijeka drugog izbora, bila je oko $15 \%$. Sličan udio imali su cefalosporini (cefaleksin $87,8 \%$ ), a svaki peti sinusitis liječen je makrolidom (20,3\%). U literaturi je primjetna velika zastupljenost penicilinskih $\mathrm{i}$ tetraciklinskih antibiotika. Tako su ljekari u hrvatskoj studiji više propisivali amoksicilin i amoksicilin u kombinaciji sa klavulanskom kiselinomkod $70 \%$ oboljelih, dok su makrolidne antibiotike propisivali u $30 \%$ oboljelih [15]. U skandinavskim studijama antibiotik izbora bio je fenoksimetil penicilin, sa učešćem od 36 do $65 \%$ [17, 21]. Zbog sve veće rezistencije osnovnih bakterijskih patogena na makrolide oni nisu svrstani u terapiju izbora [11], iako ih evropska rinološka literatura savjetuju kao antibiotike izbora u slučaju alergije na penicilinske antibiotike [26].

Iako najčešći uzrok pneumonije u zajednici ostaje neotkriven, najčešći bakterijski patogen je Streptococcus pneumoniae, a njegova prevalencija u Evropi se procjenjuje od 19 do $34 \%$ [27,28]. Takođe, kod dokazanih pneumokoknih pneumonija nije utvrđen porast rezistencije pneumokoka na penicilinske antibiotike. Međutim, primjetan je konstantan porast rezistencije Streptococcus pneumoniaena makrolide, a trenutni podaci procjenjuju da se ta vrijednost kreće od 20 do $40 \%$. Porast rezistencije uočen je i kod tetraciklinskih antibiotika. Slični podaci dostupni su za fluorohinolone, iako je rezistencija na ovu grupu antibiotika i dalje niska [26]. S obzirom da navedeni podaci sugerišu propisivanje penicilinskih antibiotika užeg spektra (fenoksimetilpeniclin i amoksicilin) u liječenju vanbolničkih pneumonija, naši ljekari nisu se pridržavali datih smjernica. Tako su infekcije donjih respirartornih puteva (J18, J22) najrjeđe liječene penicilinskim antibioticima. Antibiotik izbora propisan je u samo 3,6\% slučajeva. Neopravdano, ljekari porodične medicine preferirali su tetracikline $(36,7 \%)$, makrolide $(32,7 \%)$ i fluorohinolone(10,2 \%). Najčešći propisani antibiotik bio je doksiciklin $(36,7 \%)$, dok je azitromicin $(24,4 \%)$ bio drugi po zastupljenosti. Slična zastupljenost tetraciklina viđena je $u$ norveškoj studiji, a kao obrazloženje navodi se strah ljekara od atipičnih pneumonija [17]. Hrvatska studija pokazuje sklonost porodičnih ljekara ka azitromicinu u liječenju vanbolničkih pneumonija, koji je prema njihovim vodičima lijek izbora za oboljele mlađe od 50 godina [15]. Ipak, penicilinski antibiotici su bili najzastupljeniji $u$ liječenju vanbolničkih pneumonija, u više evropskih istraživanja[16, 21].

Akutni bronhitisi su primarno virusna oboljenja, rijetko komplikovani bakterijskom superinfekcijom. Iako nisu indikovani u terapiji, porodični ljekari u našem istraživanja su se odlučili za antibiotsku terapiju u 77,8 \% slučajeva. Kao i u liječenju pneumonija, primjetna je velika zastupljenost tetraciklina i makrolida, dok je amoksicilin bio zastupljen u 20,7\% slučajeva. Slične propisivačke navike porodičnih ljekara u terapiji akutnog bronhititsa nađene su u istraživanjima u Danskoj i Norveškoj. Razlog za propisivanje antibiotika može ležati u strahu od komplikacija kod starijih bolesnika i nešto bržoj rezoluciji oboljenja kod mlađih bolesnika. [17, 21].

\section{Zaključak}

Upotreba antibiotika u liječenju najučestalijih ARI je prekomjerna. Posebno visoka zastupljenost nađena je u liječenju akutnih tonzilitisa i pneumonija. Porodični ljekari su se nedovoljno pridržavali preporuka važećih vodiča za ARI, a u skladu sa važećim preporukama vodiča za ARI, češće biraju antibiotik prvog izbora u liječenju akutnih tonzilitisa i sinusitisa, nego u liječenju akutnih faringitisa, bronhitisa i pneumonija.

S obzirom da problem rezistencije na antibiotike postaje globalni svjetski problem, naše istraživanje ukazuje na neophodnost racionalne upotrebe 
antibiotika, u čemu su od velike koristi svjetski i nacionalni klinički vodiči.

\section{Literatura}

1. Zdravstveno stanje stanovništva Republike Srpske, 2016. Javna zdravstvena ustanova Institut za javno zdravstvo Republike Srpske; 2016. Dostupno na: http://www.phi.rs.ba/pdf/publikacije/Zdravstveno_st anje_stanovnistva_RS_2016_web.pdf [pristupljeno 2019 Jan 24].

2. National Institute for Health and Clinical Excellence (NICE). Respiratory Tract Infections - Antibiotic Prescribing: Prescribing of Antibiotics for SelfLimiting Respiratory Tract Infections in Adults and Children in Primary Care. London: NICE; 2008. Available from: https://www.nice.org.uk/guidance/.../full-guideline196853293 [Cited 2019 April 10]

3. Ventola CL. The Antibiotic Resistance Crisis Part 1: Causes and Threats. 2015; 40(4):277-83.

4. Soldo D, Katić M. Racionalno propisivanje antibiotika u obiteljskoj medicini - prevencija rezistencije. Hrvatsko društvo obiteljskih doktora. Zagreb; 2012.

5. WHO Antimicrobial resistance: global report on surveillance 2014. World Health Organisation. Available from: http://www.who.int/drugresistance/documents/survei llancereport/en/ [cited 2019 Jan 24].

6. Tešanović $G$, Tepić R, Škrbić R, Naumović Đ. Bolesti sistema za disanje.Vodič za kliničku praksu. Ministarstvo zdravlja i socijalne zaštiti Republike Srpske. Banja Luka; 2010.

7. Bojanić L, Marković-Peković V, Škrbić R, Stojaković N, Đermanović M, Bojanić J. Recent Initiatives in the Republic of Srpska to Enhance Appropriate Use of Antibiotics in Ambulatory Care; Their Influence and Implications. Front Pharmacol. 2018;9:442.

8. Spurling GK, Del Mar CB, Dooley L, Foxlee R, Farley R. Delayed antibiotic prescriptions for respiratory infections. Cochrane Database Syst Rev. 2017; 7; 9:CD004417.

9. Zoorob R, Sidani MA, Fremont RD, Kihlberg C. Antibiotic Use in Acute Upper Respiratory Tract Infections. Am Fam Physician. 2012;86(9):817-22.

10. Pelucchi C, Grigoryan L, Galeone C, Esposito S, Huovinen P, Little P et al. ESCMID Guideline for the Management of Acute Sore Throat. Clin Microbiol Infect. 2012;18(1):1-28.

11. Chow AW, Benninger MS, Brook I, Brozek JL, Ellie Goldstein JC, Hicks AL. Executive Summary:
IDSA Clinical Practice Guideline for Acute Bacterial Rhinosinusitis in Children and Adult. Clin Infect Dis. 2012;54(8):e72-e112.

12. Kaplan A. Canadian guidelines for acute bacterial rhinosinusitis. Can Fam Physician. 2014; 60(3):22734.

13. Wald ER, Applegate KE, Bordley C, Darrow DH, Glode MP, Marcy SM et al.Clinical Practice Guideline for the Diagnosis and Management of Acute Bacterial Sinusitis in Children Aged 1 to 18 Years. Pediatrics 2013;132(1);e262-80.

14. Rosenfeld RM. Acute Sinusitis in Adults. N Engl J Med. 2016; 375:962-70.

15. Vrebalo Cindro M, Tomičić M, Vruntić Vukadin K, Zokić N, Pavelin Lj, Petrić D. Propisivanje antibiotika za akutne dišne infekcije u obiteljskoj medicini u Splitu. Med Fam Croat. 2016;1(24):1118.

16. Dolk FCK, Pouwels KB, Smith DRM, Robotham $\mathrm{JV}$, Smieszek T. Antibiotics in primary care in England: which antibiotics are prescribedand for which conditions? J Antimicrob Chemother. 2018; 73(2):ii2-ii10.

17. Gjelstad S, Dalen I, Lindbæk M. GPs' antibiotic prescription patterns for respiratory tract infections still room for improvement. Cand J Prim Health Care. 2009; 27(4): 208-15.

18. Ivanovska V, Hek K, Mantel Teeuwisse AK, Leufkens HG, Nielen MM, van Dijk L. Antibiotic prescribing for children in primary care and adherence to treatment guidelines. J Antimicrob Chemother. 2016; 71(6):1707-14.

19. O'Connor R, O'Doherty J, O'Regan A, Dunne C. Antibiotic use for acute respiratory tract infections (ARTI) in primary care; what factors affect prescribing and why is it important? A narrative review. Ir J Med Sci. 2018;187(4):969-86.

20. Gulliford MC, Dregan A, Moore MV, Ashworth M, van Staa T, McCann G et al. Continued high rates of antibiotic prescribing to adults with respiratory tract infection: survey of $568 \mathrm{UK}$ general practices. BMJ Open. 2014; 4:e006245.

21. Aabenhus R, Hansen MP, Saust LT, Bjerrum L. Characterisation of antibiotic prescriptions for acute respiratory tract infections in Danish general practice: a retrospective registry based cohort study. NPJ Prim Care Respir Med. 2017;27(1):37.

22. Fleming-Dutra KE, Hersh AL, Shapiro DJ, Bartoces M, Enns EA, File TM Jret al. Prevalence of Inappropriate Antibiotic Prescriptions Among US Ambulatory Care Visits, 2010-2011. JAMA 2016;315(17):1864-73. 
23. European Centre for Disease Prevention and Control. Antimicrobial consumption. In: ECDC. Annual epidemiological report for 2016. Stockholm: ECDC; 2018. Available

from:https://ecdc.europa.eu/en/publicationsdata/antimicrobial-consumption-annualepidemiological-report-2016 [Cited 2019 Feb 25]

24. Acimis NM, Yazici AC, Gocmen L, Mas R. The prevalence of prescribing antibiotics by primary health care physicians in Turkey: A multi-centered survey. Pak J Med Sci. 2009;25(5):706-11.

25. Yuniar CT, Anggadiredja K, Islamiyah AN. Evaluation of Rational Drug Use for Acute Pharyngitis Associated with the Incidence and Prevalence of the Disease at Two Community Health Centers in Indonesia. Sci Pharm. 2017; 85(2):22.
26. Shulman ST, Bisno AL, Clegg HW, Gerber MA, Kaplan EL, Lee G et al. Clinical practice guideline for the diagnosis and management of group A streptococcal pharyngitis: 2012 update by the Infectious Diseases Society of America. Clin Infect Dis. 2012;55(10):1279-82.

27. Cilloniz C, Martin Loeches I, Garcia Vidal C, San Jose A, Torres A. Microbial Etiology of Pneumonia: Epidemiology, Diagnosis and Resistance Patterns. Int J Mol Sci. 2016; 17(12): 2120.

28. Cherazard R, Epstein M, Doan TL, Salim T, Bharti S, Smith MA. Antimicrobial Resistant Streptococcus pneumoniae: Prevalence, Mechanisms, and Clinical Implications. Am J Ther. 2017;24(3):e361-e369.

\begin{abstract}
Introduction: Acute respiratory infections (ARI) are one of the most common reasons to visit a family physician. Although viruses are responsible for the majority of ARI, antibiotic use in these infections is far too often. In Republika Srpska, guidelines for the most common acute respiratory infections of children and adults are available for family physicians.

Aim: Assessment of antibiotic prescribing frequency in ARI in family medicine in Primary Care Center Banja Luka and compatibility of prescribed antibiotic therapy and guidelines for ARI.

Method: A retrospective study in nine family medicine teams of Primary Care Center Banja Luka was conducted from 1st January till 31st December of 2017. Persons affected by acute sinusitis, tonsilopharyngitis, bronchitis, pneumonia and non-specific inflammations of lower respiratory tract were analyzed. Participants' socio-demographic characteristics, possible antibiotic treatment, compatibility of prescribed antibiotic therapy and guidelines for ARI were also analyzed.

Results: Out of 2446 participants, even 2035 (83,2\%) were prescribed an antibiotic. The representation of antibiotic prescription was $>95 \%$ in tonsillitis and pneumonia treatment. Even 60,7\% of prescribed antibiotics did not follow the recommendations of ARI guidelines. Penicillin antibiotics were prescribed in $67 \%$ of cases. The most prescribed antibiotic was amoxicillin 822 (40,4\%), followed by phenoxymethylpenicillin 318 (15,6\%), azytromycine 239 (11,7\%), doxycyclin 225 (11,1\%), and amoxicillin clavulanic acid 196 (9,5\%).

Conclusion: In family medicine practice, antibiotics were highly present in treatment of ARI. The guidelines implementation in selecting an antibiotic for the treatment of ARI was far too inconsiderable. Doctors more often prescribe the antibiotic of first choice in treating acute tonsillitis and sinusitis, than in treating acute pharyngitis, bronchitis and pneumonia.
\end{abstract}

Key words: ARI, antibiotics, guidelines for ARI

Corresponding author:

Brankica Marković

E-mail:pahuljica4u@yahoo.com

Tel. +38765944797

Presenting author:

Verica Petrović

E-mail:drverica@hotmail.com

Tel.+38765638828 
